Review

\title{
Endophytic Fungi of Citrus Plants
}

\author{
Rosario Nicoletti ${ }^{1,2}$ (1) \\ 1 Council for Agricultural Research and Economics, Research Centre for Olive, Citrus and Tree Fruit, \\ 81100 Caserta, Italy; rosario.nicoletti@crea.gov.it \\ 2 Department of Agricultural Sciences, University of Naples Federico II, 80055 Portici, Italy
}

Received: 12 October 2019; Accepted: 19 November 2019; Published: 21 November 2019

\begin{abstract}
Besides a diffuse research activity on drug discovery and biodiversity carried out in natural contexts, more recently, investigations concerning endophytic fungi have started considering their occurrence in crops based on the major role that these microorganisms have been recognized to play in plant protection and growth promotion. Fruit growing is particularly involved in this new wave, by reason that the pluriannual crop cycle likely implies a higher impact of these symbiotic interactions. Aspects concerning occurrence and effects of endophytic fungi associated with citrus species are revised in the present paper.
\end{abstract}

Keywords: Citrus spp.; endophytes; antagonism; defensive mutualism; plant growth promotion; bioactive compounds

\section{Introduction}

Despite the early pioneering observations dating back to the nineteenth century [1], a settled prejudice that pathogens basically were the only microorganisms able to colonize living plant tissues has long delayed the awareness that endophytic fungi are constantly associated to plants, and remarkably influence their ecological fitness. Overcoming an apparent vagueness of the concept of 'endophyte', scientists working in the field have agreed on the opportunity of delimiting what belongs to this functional category. Thus, a series of definitions have been enunciated which are all based on the condition of not causing any immediate overt negative effect to the host [2].

Besides being prompted by the general theoretical intent that all components of biodiversity from natural contexts ought to be exploited for the benefit of humanity, investigations on the endophytic microbiota, or endosphere [3], have also been undertaken with reference to crops. In this respect, it can be said that endophytes are even more relevant in orchards, where the time factor confers higher impact to the establishment of an equilibrium among the species which are part of the tree biocoenosis, and to its possible disruption. Hence, all sorts of contributions have recently been proliferating in the literature, to such an extent that an organization of the available information is now appropriate in order to support the scientific community in achieving further progress. In view of this perspective, the present paper offers a review of the state-of-the-art of research concerning occurrence and effects of endophytic fungi associated with citrus species.

\section{Endophytic Occurrence of Citrus Pathogens}

The agent of citrus black spot (CBS) Phyllosticta citricarpa, also known under the teleomorph name Guignardia citricarpa (Dothideomycetes, Botryosphaeriaceae), is one of the most noxious pests of these crops in subtropical regions, and it is subject to phytosanitary restrictions by the European Union and the United States. The employment of biomolecular methods has provided substantial support to the distinction between pathogenic isolates, typically slow-growing in axenic cultures and producing a yellow halo on oatmeal agar, and non-pathogenic isolates, which are morphologically 
similar but fast-growing, and producing conidia embedded within a thicker mucoid sheath [4-8]. The latter, characterized as a different species (Phyllosticta capitalensis), are known to be ubiquitous as endophytes in woody plants, having been reported from at least 70 botanical families $[6,9,10]$. Guignardia endophyllicola, treated as a separate species in a work also emphasizing its widespread endophytic occurrence [11], is at present recognized as a synonym. Differences between the two sister species also concern their metagenetic cycle. In fact, it has been ascertained that P. citricarpa is heterothallic, while P. capitalensis is homothallic [8]. This consolidated taxonomic distinction supports the exclusion from quarantine measures of plant material harbouring P. capitalensis. To this purpose, several rapid PCR assays have been developed [12-20]. The applicative use of these assays has enabled to exclude the presence of the pathogen in New Zealand, unlike what was previously assumed [21], and has supported the hypothesis of the possible endophytic occurrence of P. citricarpa in asymptomatic Citrus spp., as pointed out by several investigations (Table 1). Moreover, the two species have been clearly differentiated on account of their enzymatic profiles, with a higher expression of amylases, endoglucanases, and pectinases in P. citricarpa, suggesting a likely involvement of these enzymes in the pathogenic aptitude of the CBS agent [22]. Differences in terms of pathogenesis-related proteins have been confirmed after the genome sequencing of the two species, disclosing a higher number of coding sequences in P. citricarpa $(15,206$ versus 14,797). Such a difference has been interpreted considering the presence of growth and developmental genes involved in the expression of pathogenicity [23].

The issue of detection of contaminated material imported from areas where the pathogen is endemic has also prompted investigations concerning the assortment of Phyllosticta spp. able to colonize citrus plants in either symptomatic or latent courses. Several revisions have been published [17,24], and novel species characterized, which consistently enlarge the citrus-associated consortium within this widespread genus. Particularly, the pathogenic P. citriasiana from south-east Asia [25], P. citrichinaensis from China [26], P. citrimaxima from Thailand [24], and P. paracitricarpa from Greece [27], and the non-pathogenic endophytic P. citribraziliensis from Brazil [28] and P. paracapitalensis from New Zealand, Italy, and Spain [27]. The isolation by the latter research group of P. citricarpa from specimen collected in citrus groves in Italy, Malta, and Portugal, following analogue findings in Florida [19,29], is expected to provide impulse for a more thorough assessment of distribution and pathogenicity of this species [30]. A very recent investigation carried out in Australia on several Citrus spp. and growing conditions, has disclosed P. paracapitalensis to be even more widespread than P. capitalensis. Strains of both species were confirmed to be non-pathogenic on fruits under field conditions, and displayed antagonistic effects against the CBS agent, introducing their possible exploitation in the integrated management of this disease [31]. In this respect, it has been speculated that, rather than depending on intrinsic genetic factors, resistance to CBS by C. latifolia could be due to its systematic colonization by P. capitalensis, as disclosed by a dedicated investigation carried out in Brazil [32].

Colletotrichum (Sordariomycetes, Glomerellaceae) is another important ascomycete genus in course of coherent taxonomic revision. Besides Colletotrichum gloeosporioides, the agent of citrus anthracnose, it includes many species known for their endophytic aptitude. A recent investigation carried out in China on several Citrus spp. has shown a high proportion of endophytic strains to belong to $C$. gloeosporioides sensu stricto, calling for further investigations concerning the asymptomatic occurrence of this pathogen in citrus orchards. Additional identified species are Colletotrichum fructicola from Citrus reticulata cv. Nanfengmiju and Citrus japonica (=Fortunella margarita), and Colletotrichum karstii [33]. A similar widespread occurrence of C. gloeosporioides has been more recently confirmed in Brazil, where just one out of 188 isolates was found to be able to induce post-bloom fruit drop. This syndrome is more frequently associated to the species Colletotrichum abscissum, which, however, does not display an endophytic habit [34]. Endophytic C. gloeosporioides were also previously reported from Citrus limon in Argentina [35] and Cameroon [36].

One more meaningful example of endophytic fungus converting to pathogenic when plants are exposed to stress factors is represented by another member of the Botryosphaeriaceae, Lasiodiplodia theobromae. Characterized by a widespread endophytic occurrence $[37,38]$, this species has been 
reported to exacerbate pre-harvest fruit drop and post-harvest fruit decay in plants of Citrus sinensis hit by the huanglongbing syndrome [39].

A quite intricate case deserving further investigations with reference to the epidemiological impact by endophytic strains is represented by members of the genus Diaporthe (Sordariomycetes, Diaporthaceae), also known under the anamorph name Phomopsis [40,41], which are widespread in different ecological contexts [41,42]. Besides the longtime known D. citri, more species in this genus have been recently identified as the causal agents of melanose, stem-end rot, and gummosis on Citrus spp., particularly, D. citriasiana and D. citrichinensis in China [43], and D. limonicola, D. melitensis, D. baccae, D. foeniculina, and D. novem in Europe [44]. Even more species have been reported for their endophytic occurrence as a result of a phylogenetic reassessment carried out in China, with eight known (D. arecae species complex, D. citri, D. citriasiana, D. citrichinensis, D. endophytica, D. eres, D. hongkongensis, and D. sojae) and seven new species (D. biconispora, D. biguttulata, D. discoidispora, D. multiguttulata, D. ovalispora, D. subclavata, and D. unshiuensis) [45].

Table 1. Endophytic fungi reported from Citrus species.

\begin{tabular}{|c|c|c|c|}
\hline Endophyte $^{1}$ & Plant Species & Country & Reference \\
\hline \multirow{4}{*}{ Alternaria alternata } & C. limon, C. tangelo & Florida & [46] \\
\hline & Citrus spp. & Japan & [47] \\
\hline & C. limon & Argentina & [35] \\
\hline & C. reticulata & Iran & [48] \\
\hline Alternaria brassicicola & C. reticulata & Iran & [48] \\
\hline Alternaria carthami & C. reticulata & Iran & [48] \\
\hline Alternaria citri & C. sinensis & Iran & [49] \\
\hline Alternaria infectoria & C. sinensis & Iran & [49] \\
\hline Alternaria rosae & C. sinensis & Iran & [49] \\
\hline \multirow{2}{*}{ Alternaria sp. } & C. kotokan & Taiwan & [52] \\
\hline & C. sinensis & Iran & [49] \\
\hline Annulohypoxylon stygium & C. sinensis & Iran & [49] \\
\hline Arthrinium sp. & C. japonica & Taiwan & [52] \\
\hline Ascochyta medicaginicola & C. reticulata & Iran & [48] \\
\hline Aspergillus nidulans & C. sinensis & Iran & [49] \\
\hline Aspergillus niger & C. reticulata & Iran & [48] \\
\hline Aspergillus pallidofulvus & C. reticulata & Iran & [48] \\
\hline Aspergillus terreus & C. sinensis & Iran & [49] \\
\hline Aureobasidium iranianum & C. reticulata & Iran & [48] \\
\hline \multirow[t]{2}{*}{ Aureobasidium melanogenum } & C. reticulata & Iran & [48] \\
\hline & C. sinensis & Brazil & [53] \\
\hline \multirow[t]{2}{*}{ Aureobasidium pullulans } & C. japonica & Uruguay & [54] \\
\hline & C. reticulata & Iran & [48] \\
\hline Beauveria bassiana & C. limon & China & [55] \\
\hline Biscogniauxia mediterranea & C. sinensis & Iran & [49] \\
\hline Biscogniauxia nummularia & C. sinensis & Iran & [49] \\
\hline Bjerkandera adusta & C. sinensis & Iran & [49] \\
\hline Botryosphaeria sp. & C. aurantium & Taiwan & [52] \\
\hline Camarosporium sp. & C. aurantium, C. medica var. sarcodactylis & Taiwan & [52] \\
\hline Candida parapsilosis & C. sinensis & Brazil & [53] \\
\hline \multirow{2}{*}{ Cercospora sp. } & C. limon & Cameroon & [36] \\
\hline & C. sinensis & Iran & [49] \\
\hline Chaetomium globosum & C. sinensis & Iran & [49] \\
\hline Chaetomium sp. & C. sinensis & Taiwan & [52] \\
\hline Cladosporium cladosporioides & C. reticulata & Iran & [48] \\
\hline Cladosporium sp. & $\begin{array}{c}\text { C. limon, C. reshni, C. sinensis, C. sunki, } \\
\text { C. trifoliata, C. volkameriana }\end{array}$ & Brazil & [56] \\
\hline Cladosporium xanthochromaticum & C. reticulata & Iran & {$[48]$} \\
\hline \multirow{2}{*}{ Colletotrichum boninense } & C. limon & Cameroon & [36] \\
\hline & C. sinensis & Iran & [49] \\
\hline
\end{tabular}


Table 1. Cont.

\begin{tabular}{|c|c|c|c|}
\hline Endophyte $^{1}$ & Plant Species & Country & Reference \\
\hline \multirow[t]{2}{*}{ Colletotrichum fructicola } & C. japonica, C. reticulata & China & [43] \\
\hline & $\begin{array}{l}\text { C. limon, C. reshni, C. sinensis, C. sunki, } \\
\text { C. trifoliata, C. volkameriana }\end{array}$ & Brazil & {$[56]$} \\
\hline \multirow{4}{*}{ Colletotrichum gloeosporioides } & & Argentina & [35] \\
\hline & C. limon & Cameroon & [36] \\
\hline & C. grandis, C. reticulata, C. sinensis, C. unshiu & China & [43] \\
\hline & C. sinensis & Iran & [49] \\
\hline Colletotrichum karstii & C. grandis, C. limon & China & [43] \\
\hline \multirow{3}{*}{ Colletotrichum sp. } & $\begin{array}{c}\text { C. aurantium, C. medica var. sarcodactylis, } \\
\text { C. sinensis }\end{array}$ & Taiwan & {$[52]$} \\
\hline & C. deliciosa, C. reticulata & Brazil & [57] \\
\hline & C, aurantifolia & India & [58] \\
\hline Coprinellus radians & C. sinensis & Iran & [49] \\
\hline Coprinopsis sp. & C. medica & Taiwan & [52] \\
\hline Cryptococcus flavescens & C. sinensis & Brazil & [53] \\
\hline Cryptococcus laurentii & C. sinensis & Brazil & [53] \\
\hline Cyanodermella sp. & C. medica var. sarcodactylis, Citrus sp. & Taiwan & [52] \\
\hline Diaporthe arecae s.c. ${ }^{2}$ & $\begin{array}{c}\text { C. grandis, C. limon, C. reticulata, C. sinensis, } \\
\text { Citrus sp., C. unshiu }\end{array}$ & China & [45] \\
\hline Diaporthe biconispora $^{2, *}$ & C. grandis, C. japonica, C. sinensis & China & [45] \\
\hline Diaporthe biguttulata ${ }^{2, *}$ & C. limon & China & [45] \\
\hline Diaporthe citri ${ }^{2}$ & C. reticulata, C. unshiu & China & {$[43,45]$} \\
\hline Diaporthe citriasiana $^{2}$ & C. unshiu & China & {$[43]$} \\
\hline Diaporthe citrichinensis ${ }^{2}$ & C. grandis, C. japonica & China & [45] \\
\hline Diaporthe discoidispora ${ }^{2, *}$ & C. sinensis, C. unshiu & China & [45] \\
\hline Diaporthe endophytica ${ }^{2}$ & C. limon & China & [45] \\
\hline Diaporthe eres ${ }^{2}$ & C. japonica, Citrus sp., C. unshiu & China & [45] \\
\hline Diaporthe eucalyptorum ${ }^{2}$ & C. limon & Cameroon & {$[36]$} \\
\hline Diaporthe foeniculina ${ }^{2}$ & C. sinensis & Iran & [49] \\
\hline Diaporthe hongkongensis 2 & C. grandis, C. reticulata, C. sinensis, C. unshiu & China & [45] \\
\hline Diaporthe multiguttulata ${ }^{2, *}$ & C. grandis & China & [45] \\
\hline Diaporthe ovalispora ${ }^{2, *}$ & C. limon & China & [45] \\
\hline Diaporthe phaseolorum $^{2}$ & C. limon & Cameroon & {$[36]$} \\
\hline \multirow[t]{2}{*}{ Diaporthe sojae ${ }^{2}$} & C. limon, C. reticulata, C. unshiu & China & [45] \\
\hline & C. limon & Cameroon & [36] \\
\hline \multirow{3}{*}{ Diaporthe sp. ${ }^{2}$} & C. aurantium, C. medica, C. sinensis & Taiwan & {$[52]$} \\
\hline & C. japonica & China & [45] \\
\hline & C. reticulata & Iran & [48] \\
\hline Diaporthe unshiuensis ${ }^{2, *}$ & C. japonica & China & [45] \\
\hline Didymella microchlamydospora & C. reticulata & Iran & [48] \\
\hline Discostroma sp. & C. medica & Taiwan & {$[52]$} \\
\hline Epicoccum nigrum & C. sinensis & Iran & [49] \\
\hline Eutypella sp. & C. medica var. sarcodactylis & Taiwan & [52] \\
\hline Fusarium culmorum & C. sinensis & Iran & [49] \\
\hline Fusarium incarnatum & C. sinensis & Iran & [49] \\
\hline Fusarium oxysporum & C. reticulata & Iran & [48] \\
\hline Fusarium proliferatum & C. sinensis & Iran & [49] \\
\hline Fusarium sarcochroum & C. limon, C. reticulata & Italy, Spain & [50] \\
\hline \multirow{2}{*}{ Fusarium sp. } & C. sinensis & Taiwan & [52] \\
\hline & C. reticulata & Iran & [48] \\
\hline Hanseniaspora opuntiae & C. reticulata & China & [59] \\
\hline Hypholoma fasciculare & C. sinensis & Iran & [49] \\
\hline Hypoxylon investiens & C. sinensis & Iran & [49] \\
\hline Lasiodiplodia theobromae & C. sinensis & China & [39] \\
\hline Lasmenia sp. & C. medica var. sarcodactylis & Taiwan & {$[52]$} \\
\hline Meira geulakonigae & C. paradisi & Israel & {$[60]$} \\
\hline Meyerozyma caribbica & C. reticulata & Iran & [48] \\
\hline \multirow{2}{*}{ Meyerozyma guilliermondii } & C. sinensis & Brazil & [53] \\
\hline & C. reticulata & China & [58] \\
\hline Muscodor sp. & C. sinensis & Brazil & [61] \\
\hline Mycoleptodiscus sp. & C. aurantium & Taiwan & {$[52]$} \\
\hline Mycosphaerella sp. & C. limon & Cameroon & [36] \\
\hline Myrothecium sp. & C. reticulata & Iran & [48] \\
\hline Neocosmospora solani & C. reticulata & Iran & [48] \\
\hline
\end{tabular}


Table 1. Cont.

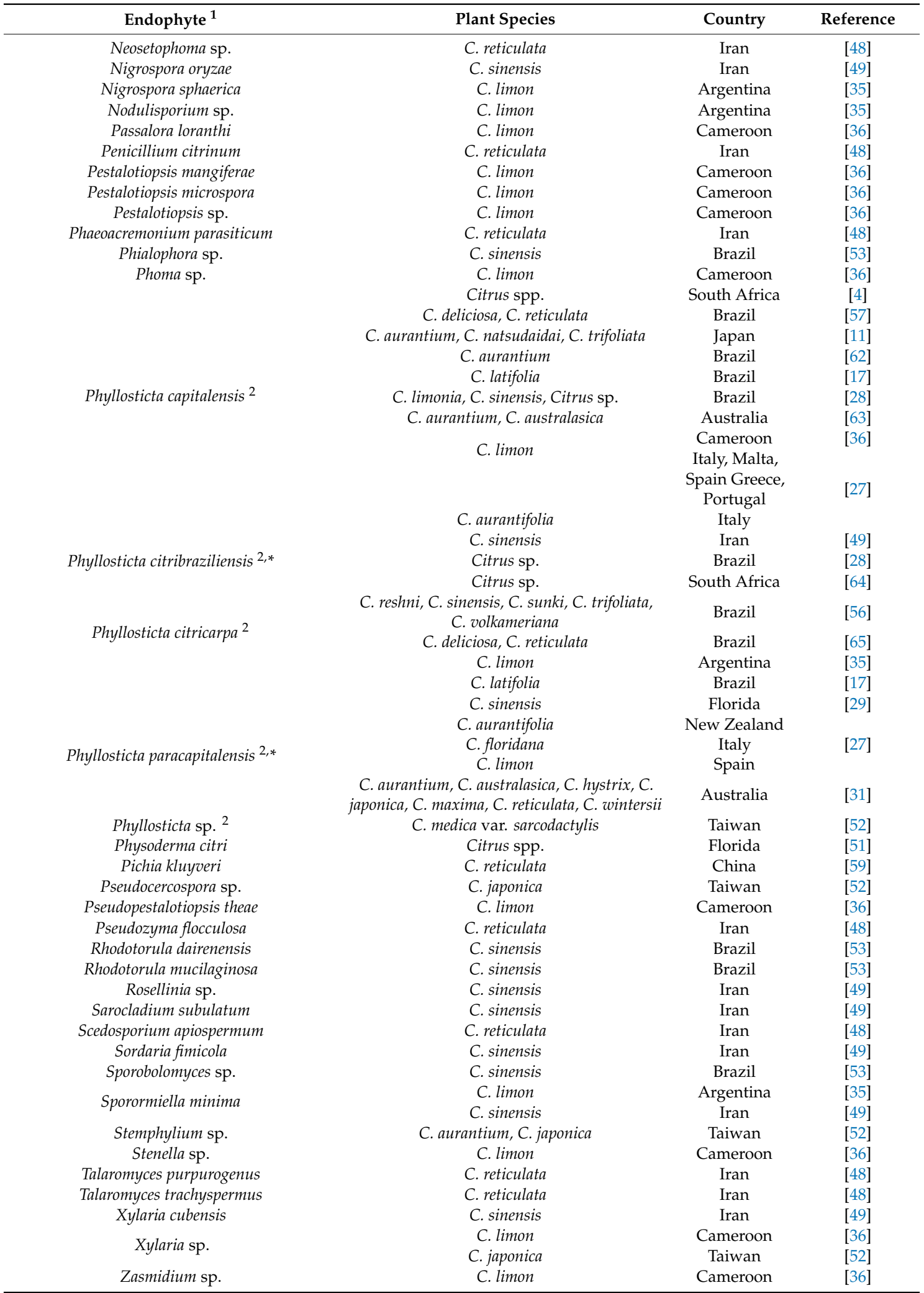

\footnotetext{
${ }^{1}$ Species are reported according to the latest accepted name, which might not correspond to the one used in the corresponding reference. ${ }^{2}$ Conforming to the principle 'one fungus- - one name' [66], the older genus names Diaporthe and Phyllosticta have been considered to deserve priority over Phomopsis and Guignardia, respectively. * Novel species described for the first time from this plant source.
} 
Endophytic occurrence has also been reported for other citrus pathogens, such as the leaf-spot agents Alternaria alternata [35,46-48] and Alternaria citri [49], Fusarium oxysporum [48], and Fusarium sarcochroum, known as a possible agent of dieback of twigs on mandarin and lemon [50]. The latter study also introduces new Fusarium spp. (F. citricola, F. salinense, F. siculi), causing cankers on several citrus species. Considering that pathogenic Fusaria often present an early latent stage, this finding claims for further assessments concerning their possible endophytic occurrence. Finally, it is worth mentioning Physoderma citri, a species ascribed to the phylum Blastocladiomycota reported to cause vessel occlusion, but also found in asymptomatic plants of several Citrus spp. [51].

\section{Other Endophytic Fungi and Their Interactions with Pests and Pathogens of Citrus}

Besides the above reports, essentially dedicated to pathogenic species/genera upon the aim to assess the epidemiological impact of latent endophytic stages, additional data have been recorded on the overall species assemblage in a few contexts (Table 1). A study carried out on C. limon in Cameroon [36] pointed out that yellowing of leaves affects foliar endophytic communities, and that interactions among endophytes may be a factor driving the yellowing process. In fact, yellow leaves presented a less varied species assortment dominated by C. gloeosporioides in the absence of species belonging to the Mycosphaerellaceae, otherwise common in healthy leaves. In vitro observations in dual cultures showed that the latter were inhibited and overgrown by C. gloeosporioides, even if capable to revert this inhibitory effect when pre-inoculated, which was interpreted as deriving from production of fungitoxic metabolites. This study also demonstrated a low occurrence of species in the Xylariaceae, which are usually quite widespread as tree endophytes $[67,68]$.

The endophytic occurrence of a few yeast species was documented in an investigation carried out on C. sinensis in Brazil [53]. By means of scanning electron microscopy, it was observed that these microorganisms are mostly localized around stomata and in xylem vessels. Isolates of the species Rhodotorula mucilaginosa, Meyerozyma (Pichia) guilliermondii, and Cryptococcus flavescens were inoculated in healthy plants, and re-isolated, without causing any kind of disease symptoms. Quite interestingly, the authors noted that M. guilliermondii primarily occurred in plants colonized by Xylella fastidiosa, the causal agent of citrus variegated chlorosis (CVC), and that the bacterium could thrive on a supernatant separated from cultures of a strain of this species. This finding represents an indication that the presence of the yeast could stimulate the pathogen and could be responsible for more severe disease symptoms. More recently, strains of M. guilliermondii have been recovered, along with strains of Hanseniaspora opuntiae and Pichia kluyveri, from tangerine peel in China. However, it is questionable if this record can actually concern endophytic occurrence considering that authors refer that fruits were purchased on the market rather than being directly collected in the field [59].

Indeed, interactions between endophytic bacteria and fungi are complex, and the assortment of strains which can be recovered is largely influenced by the antagonistic interactions as mediated by the production of antibiotics. In this respect, strains of P. citricarpa isolated from Citrus spp. in Brazil were found to possess inhibitory properties toward several endophytic Bacillus spp. from the same source, while a stimulatory effect was assessed towards the gram-negative Pantoea agglomerans, which can be taken as an indication of the opportunity to investigate possible interference with the development of X. fastidiosa [56].

Antagonistic properties by an isolate of Muscodor sp. from C. sinensis were reported against P. citrocarpa as deriving from the production of volatile organic compounds (VOCs) [61]. Actually, such properties are known for endophytic isolates of Muscodor and other genera of xylariaceous fungi, such as Hypoxylon (=Nodulisporium) and Xylaria, reported from many plant species [69] and also occurring in citrus plants $[35,36,49,52]$.

Endophytic strains belonging to two species of Diaporthe, D. terebinthifolii and the already-mentioned $D$. endophytica, displayed inhibitory properties against $P$. citrocarpa in vitro and on detached fruits. Moreover, their transformants expressing the fluorescent protein DsRed proved to be able to actively colonize citrus seedlings, and to remain viable in the plant tissues for one year at least. These evidences support their 
possible use in the biocontrol of this pathogen [70]. Antifungal properties have also been reported for a strain of another fungus belonging to the Diaporthales (Lasmenia sp.), which was recovered from C. medica var. sarcodactylis [52].

Rather than just concerning agents of cryptogamic diseases, protective effects by endophytic fungi may pertain several kinds of pests [71,72]. Actually, data available in the literature concerning citrus plants are limited but encourage further assessments. For instance, a ustilaginomycetous yeast endophytic in grapefruit (Citrus paradisi), Meira geulakonigae, was found to be able to reduce populations of the citrus rust mite (Phyllocoptruta oleivora) [60]. More recently, two strains of Beauveria bassiana were inoculated in seedlings of $C$. limon through foliar sprays and proved to be able to colonize the plants endophytically. Besides increasing plant growth, they caused $10 \%-15 \%$ mortality on adults of the Asian citrus psyllid (Diaphorina citri), and the females feeding on the treated plants laid significantly fewer eggs [55]. It is not unlikely that more evidence in this respect can be gathered from targeted investigations concerning naturally occurring endophytes, considering that protective effects have been documented for endophytic strains of F. oxysporum against aphids [73] and nematodes [74].

As a general ecological trait, endophytic fungi seem to be absent in seeds of citrus species [65]. This is to be taken as an indication that these microorganisms are not adapted to a vertical spread, and most likely colonize citrus plants coming from the surrounding environment.

\section{Biotechnological Implications}

The involvement of endophytic fungi in a tripartite relationship with the host plant and its pests and pathogens highlights their basic role in establishing an equilibrium in such a fragile biocoenosis. Indeed, a major biotechnological application of endophytic strains consists in the exploitation of their aptitude to defensive mutualism.

The endophytic habit is conducive for interactions with other microorganisms sharing the same micro-environment. There is strong evidence that these interactions entangle the genetic level, and that interspecific transfer of gene pools regularly occurs. Probably, the best example in this respect is represented by genes encoding for the synthesis of polyketide secondary metabolites, which are usually grouped in clusters and are influenced in their expression by several external factors [75,76]. Horizontal gene transfer from other endophytic microorganisms may eventually explain the ability by a strain of P. citricarpa [77] to produce the blockbuster drug taxol, first extracted from Taxus spp. and afterwards as a secondary metabolite of a high number of endophytic fungi $[69,78]$.

P. citricarpa has been further characterized with reference to production of secondary metabolites. Particularly, it has been reported to produce the new dioxolanone phenguignardic acid butyl ester, along with four previously reported compounds: phenguignardic acid methyl ester, peniisocoumarin G, protocatechuic acid, and tyrosol [79]. Phyllosticta spp. have been reported to have a similar metabolomic profile, including the dioxolanone phytotoxins which are regarded as potential virulence factors. However, one of these products, guignardic acid, has also been reported from P. capitalensis [80]. Biosynthetic abilities by endophytic strains of the latter species also refer to meroterpenes, such as compounds in the guignardone series [81-84] and the manginoids [85]. Besides a likely implication in the relationships with other citrus-associated microbial species, the bioactive properties of the dioxolanones and the related meroterpene compounds deserve to be further investigated in view of possible pharmaceutical exploitation $[79,86]$.

Protocatechuic acid was again reported from an unidentified fungal strain recovered from leaves of Citrus jambhiri, along with indole-3-acetic acid (IAA) and acropyrone [87]. The latter compound was shown to possess antibiotic properties against Staphylococcus aureus, while the finding of IAA is in line with the many reports of plant hormones produced by endophytic fungi [69], which at least in part unfold the growth-promoting effects exerted on their hosts $[88,89]$. Production of IAA was also reported from strains of the yeasts Hanseniaspora opuntiae and Meyerozyma guilliermondii from Citrus reticulata, which were able to induce growth-promoting effects on seedlings of Triticum aestivum [59]. 
The above-mentioned VOCs reported from an endophytic strain of Muscodor sp. from C. sinensis include several sesquiterpenes, namely azulene, cis/trans- $\alpha$-bergamotene, cedrene, (Z)- $\beta$-farnesene, farnesene epoxide, $\alpha$-himachalene, $\alpha$-longipinene, thujopsene, 2,4,6-trimethyl-1,3,6-heptatriene, 2-methyl-5,7-dimethylene-1-8-nonadiene, and cis-Z-bisabolene epoxide [61]. Mixtures of these compounds have a possible biotechnological application for the mycofumigation of fruits, proposed for the control of CBS and various post-harvest pathogens [90-92]. Concerning VOCs, another possible investigational subject consists in assessing if any endophyte of citrus plants is able to produce compounds occurring in the typical aroma spread by flowers and fruits of these plants, which are exploited by the pharmaceutical and the perfume industries. In this respect, the production of bergapten, a psoralen compound known from bergamot (Citrus bergamia), has already been pointed out by endophytic strains of Penicillium sp. [93] and L. theobromae [94]. Although these findings concern plants other than citrus, it is worth considering that these fungi are also reported as citrus endophytes (Table 1).

Antimicrobial properties of fungi do not just depend on the production of bioactive compounds. In fact, a strain of P. capitalensis (Bios PTK 4) recovered from an unidentified citrus plant was found to be able to synthesize silver nanoparticles extracellularly. These nanoparticles, which were spherical, 5-30 nm in size, well-dispersed, and extremely stable, have been characterized for their antibacterial and antifungal properties [95].

\section{Conclusions}

Revision of literature in the field shows that a major part of the research activity carried out on endophytic fungi of citrus plants consists in investigations on the occurrence of pathogens, and their discrimination from other ecologically associated taxa. Such a limited approach has, anyway, turned to be useful to disclose an epidemiological relevance of these microorganisms, as related to a modulatory role in the spread of citrus diseases. On that account, possible interactions in conducive contexts with other important pathogens, such as the agent of mal secco Phoma tracheiphila and species of Phytophthora causing foot and root rot, should be attentively considered. Even when there is no apparent direct interaction with disease agents, such as in the cases of CVC incited by X. fastidiosa, tristeza, and other viroses, the possible effect by endophytic fungi in stimulating plant defense reaction, or, more in general, to act as plant disease modifiers [96], should not be disregarded. In this respect, data concerning occasional isolations might well disclose some relevance. Unfortunately, description of the endophytic assemblages in several papers is often approximate or incomplete, such as in a mentioned survey concerning sweet orange (C. sinensis), where just a single strain was characterized out of a sample of over 400 endophytes [61]. It is to be recommended that future investigations in the field be more circumstantial in their approach to describe this component of biodiversity, in the aim of increasing opportunities for its biotechnological exploitation.

Encouraging examples in this direction are represented by two very recent publications from Iran $[48,49]$. Indeed, the focus on endophytic fungi is gradually evolving from a basically descriptive phase to the analysis of factors influencing the structure and composition of microbiomes, in view of their manipulation for increasing plant protection and productivity. A better comprehension of the already introduced genetic interactions among members of the associated biota and the host tree is crucial for the success of any practical application of endophytic fungi in sustainable agriculture [97]. Moreover, the observed effects of the host genotype $[98,99]$ could be adequately considered in breeding programs, in the aim to select suitable recipient genotypes for fungal inoculants.

Funding: This research received no external funding.

Conflicts of Interest: The author declares no conflict of interest. 


\section{References}

1. De Bary, A. Morphologie und Physiologie der Pilze, Flechten und Myxomyceten; Engelmann: Leipzig, Germany, 1866.

2. Hyde, K.D.; Soytong, K. The fungal endophyte dilemma. Fungal Divers. 2008, 33, 163-173.

3. Turner, T.R.; James, E.K.; Poole, P.S. The plant microbiome. Genome Biol. 2013, 14, 209. [CrossRef] [PubMed]

4. McOnie, K.C. The latent occurrence in Citrus and other hosts of a Guignardia easily confused with G. citricarpa, the black spot pathogen. Phytopathology 1964, 54, 64-67.

5. Meyer, L.; Slippers, B.; Korsten, L.; Kotze, J.M.; Wingfield, M.J. Two distinct Guignardia species associated with citrus in South Africa. S. Afr. J. Sci. 2001, 97, 191-194.

6. Baayen, R.P.; Bonants, P.J.M.; Verkley, G.; Carroll, G.C.; van der Aa, H.A.; de Weerdt, M.; van Brouwershaven, I.R.; Schutte, G.C.; Maccheroni, W., Jr.; Glienke de Blanco, C.; et al. Nonpathogenic isolates of the citrus black spot fungus, Guignardia citricarpa, identified as a cosmopolitan endophyte of woody plants, G. mangiferae (Phyllosticta capitalensis). Phytopathology 2002, 92, 464-477. [CrossRef]

7. Zavala, M.G.M.; Er, H.L.; Goss, E.M.; Wang, N.Y.; Dewdney, M.; van Bruggen, A.H.C. Genetic variation among Phyllosticta strains isolated from citrus in Florida that are pathogenic or nonpathogenic to citrus. Trop. Plant Pathol. 2014, 39, 119-128. [CrossRef]

8. Guarnaccia, V.; Gehrmann, T.; Silva-Junior, G.J.; Fourie, P.H.; Haridas, S.; Vu, D.; Spatafora, J.; Martin, F.M.; Robert, V.; Grigoriev, I.V.; et al. Phyllosticta citricarpa and sister species of global importance to Citrus. Mol. Plant Pathol. 2019. [CrossRef]

9. Wikee, S.; Udayanga, D.; Crous, P.W.; Chukeatirote, E.; McKenzie, E.H.; Bahkali, A.H.; Dai, D.Q.; Hyde, K.D. Phyllosticta-An overview of current status of species recognition. Fungal Divers. 2011, 51, 43-61. [CrossRef]

10. Wikee, S.; Lombard, L.; Crous, P.W.; Nakashima, C.; Motohashi, K.; Chukeatirote, E.; Alias, S.A.; McKenzie, E.H.C.; Hyde, K.D. Phyllosticta capitalensis, a widespread endophyte of plants. Fungal Divers. 2013, 60, 91-105. [CrossRef]

11. Okane, I.; Nakagiri, A.; Ito, T.; Lumyong, S. Extensive host range of an endophytic fungus, Guignardia endophyllicola (anamorph: Phyllosticta capitalensis). Mycoscience 2003, 44, 353-363. [CrossRef]

12. Bonants, P.J.; Carroll, G.C.; De Weerdt, M.; van Brouwershaven, I.R.; Baayen, R.P. Development and validation of a fast PCR-based detection method for pathogenic isolates of the citrus black spot fungus, Guignardia citricarpa. Eur. J. Plant Pathol. 2003, 109, 503-513. [CrossRef]

13. Meyer, L.; Sanders, G.M.; Jacobs, R.; Korsten, L. A one-day sensitive method to detect and distinguish between the citrus black spot pathogen Guignardia citricarpa and the endophyte Guignardia mangiferae. Plant Dis. 2006, 90, 97-101. [CrossRef]

14. Meyer, L.; Jacobs, R.; Kotzé, J.M.; Truter, M.; Korsten, L. Detection and molecular identification protocols for Phyllosticta citricarpa from citrus matter. S. Afr. J. Sci. 2012, 108, 53-59. [CrossRef]

15. Peres, N.A.; Harakava, R.; Carroll, G.C.; Adaskaveg, J.E.; Timmer, L.W. Comparison of molecular procedures for detection and identification of Guignardia citricarpa and G. mangiferae. Plant Dis. 2007, 91, 525-531. [CrossRef]

16. Van Gent-Pelzer, M.P.E.; Van Brouwershaven, I.R.; Kox, L.F.F.; Bonants, P.J.M. A TaqMan PCR method for routine diagnosis of the quarantine fungus Guignardia citricarpa on citrus fruit. J. Phytopathol. 2007, 155, 357-363. [CrossRef]

17. Baldassari, R.B.; Wickert, E.; de Goes, A. Pathogenicity, colony morphology and diversity of isolates of Guignardia citricarpa and G. mangiferae isolated from Citrus spp. Eur. J. Plant Pathol. 2008, 120, 103-110. [CrossRef]

18. Stringari, D.; Glienke, C.; Christo, D.D.; Maccheroni, W., Jr.; Azevedo, J.L.D. High molecular diversity of the fungus Guignardia citricarpa and Guignardia mangiferae and new primers for the diagnosis of the citrus black spot. Braz. Arch. Biol. Technol. 2009, 52, 1063-1073. [CrossRef]

19. Hu, J.; Johnson, E.G.; Wang, N.Y.; Davoglio, T.; Dewdney, M.M. qPCR quantification of pathogenic Guignardia citricarpa and nonpathogenic G. mangiferae in citrus. Plant Dis. 2014, 98, 112-120. [CrossRef]

20. Schirmacher, A.M.; Tomlinson, J.A.; Barnes, A.V.; Barton, V.C. Species-specific real-time PCR for diagnosis of Phyllosticta citricarpa on Citrus species. EPPO Bull. 2019. [CrossRef]

21. Everett, K.R.; Rees-George, J. Reclassification of an isolate of Guignardia citricarpa from New Zealand as Guignardia mangiferae by sequence analysis. Plant Pathol. 2006, 55, 194-199. [CrossRef] 
22. Romão, A.S.; Spósito, M.B.; Andreote, F.D.; Azevedo, J.L.D.; Araújo, W.L. Enzymatic differences between the endophyte Guignardia mangiferae (Botryosphaeriaceae) and the citrus pathogen G. citricarpa. Genet. Mol. Res. 2011, 10, 243-252. [CrossRef] [PubMed]

23. Munari Rodrigues, C.; Takita, M.A.; Silva, N.V.; Ribeiro-Alves, M.; Machado, M.A. Comparative genome analysis of Phyllosticta citricarpa and Phyllosticta capitalensis, two fungi species that share the same host. BMC Genom. 2019, 20, 554. [CrossRef]

24. Wikee, S.; Lombard, L.; Nakashima, C.; Motohashi, K.; Chukeatirote, E.; Cheewangkoon, R.; McKenzie, E.H.C.; Hyde, K.D.; Crous, P.W. A phylogenetic re-evaluation of Phyllosticta (Botryosphaeriales). Stud. Mycol. 2013, 76, 1-29. [CrossRef] [PubMed]

25. Wulandari, N.F.; Toanun, C.; Hyde, K.D.; Duong, L.M.; de Gruyter, J.; Meffert, J.P.; Groenewald, J.Z.; Crous, P.W. Phyllosticta citriasiana sp. nov., the cause of Citrus tan spot of Citrus maxima in Asia. Fungal Divers. 2009, 34, 23-39.

26. Wang, X.; Chen, G.; Huang, F.; Zhang, J.; Hyde, K.D.; Li, H. Phyllosticta species associated with citrus diseases in China. Fungal Divers. 2012, 52, 209-224. [CrossRef]

27. Guarnaccia, V.; Groenewald, J.Z.; Li, H.; Glienke, C.; Carstens, E.; Hattingh, V.; Fourie, P.H.; Crous, P.W. First report of Phyllosticta citricarpa and description of two new species, P. paracapitalensis and P. paracitricarpa, from citrus in Europe. Stud. Mycol. 2017, 87, 161-185. [CrossRef]

28. Glienke, C.; Pereira, O.L.; Stringari, D.; Fabris, J.; Kava-Cordeiro, V.; Galli-Terasawa, L.; Cunnington, J.; Shivas, R.G.; Groenewald, J.Z.; Crous, P.W. Endophytic and pathogenic Phyllosticta species, with reference to those associated with citrus black spot. Persoonia 2011, 26, 47-56. [CrossRef]

29. Schubert, T.S.; Dewdney, M.M.; Peres, N.A.; Palm, M.E.; Jeyaprakash, A.; Sutton, B.; Mondal, S.N.; Wang, N.Y.; Rascoe, J.; Picton, D.D. First report of Guignardia citricarpa associated with citrus black spot on sweet orange (Citrus sinensis) in North America. Plant Dis. 2012, 96, 1225. [CrossRef]

30. Jeger, M.; Bragard, C.; Caffier, D.; Candresse, T.; Chatzivassiliou, E.; Dehnen-Schmutz, K.; Gilioli, G.; Gregoire, J.C.; Jaques Miret, J.A.; MacLeod, A.; et al. Evaluation of a paper by Guarnaccia et al. (2017) on the first report of Phyllosticta citricarpa in Europe. EFSA J. 2018, 16, 5114.

31. Tran, N.T.; Miles, A.K.; Dietzgen, R.G.; Drenth, A. Phyllosticta capitalensis and P. paracapitalensis are endophytic fungi that show potential to inhibit pathogenic P. citricarpa on citrus. Australas. Plant Pathol. 2019, 48, 281-296. [CrossRef]

32. Wickert, E.; de Macedo Lemos, E.G.; Kishi, L.T.; de Souza, A.; de Goes, A. Genetic diversity and population differentiation of Guignardia mangiferae from "Tahiti” acid lime. Sci. World J. 2012. [CrossRef]

33. Huang, F.; Chen, G.Q.; Hou, X.; Fu, Y.S.; Cai, L.; Hyde, K.D.; Li, H.Y. Colletotrichum species associated with cultivated citrus in China. Fungal Divers. 2013, 61, 61-74. [CrossRef]

34. Waculicz-Andrade, C.E.; Savi, D.C.; Bini, A.P.; Adamoski, D.; Goulin, E.H.; Silva, G.J., Jr.; Massola, N.S., Jr.; Terasawa, L.G.; Kava, V.; Glienke, C. Colletotrichum gloeosporioides sensu stricto: An endophytic species or citrus pathogen in Brazil? Australas. Plant Pathol. 2017, 46, 191-203. [CrossRef]

35. Durán, E.L.; Ploper, L.D.; Ramallo, J.C.; Piccolo Grandi, R.A.; Hupper Giancoli, Á.C.; Azevedo, J.L. The foliar fungal endophytes of Citrus limon in Argentina. Can. J. Bot. 2005, 83, 350-355. [CrossRef]

36. Douanla-Meli, C.; Langer, E.; Mouafo, F.T. Fungal endophyte diversity and community patterns in healthy and yellowing leaves of Citrus limon. Fungal Ecol. 2013, 6, 212-222. [CrossRef]

37. Mohali, S.; Burgess, T.I.; Wingfield, M.J. Diversity and host association of the tropical tree endophyte Lasiodiplodia theobromae revealed using simple sequence repeat markers. For. Pathol. 2005, 35, 385-396. [CrossRef]

38. Slippers, B.; Wingfield, M.J. Botryosphaeriaceae as endophytes and latent pathogens of woody plants: Diversity, ecology and impact. Fungal Biol. Rev. 2007, 21, 90-106. [CrossRef]

39. Zhao, W.; Bai, J.; McCollum, G.; Baldwin, E. High incidence of preharvest colonization of huanglongbing-symptomatic Citrus sinensis fruit by Lasiodiplodia theobromae (Diplodia natalensis) and exacerbation of postharvest fruit decay by that fungus. Appl. Environ. Microbiol. 2015, 81, 364-372. [CrossRef]

40. Udayanga, D.; Liu, X.; McKenzie, E.H.C.; Chukeatirote, E.; Bahkali, A.H.A.; Hyde, K.D. The genus Phomopsis: Biology, applications, species concepts and names of common phytopathogens. Fungal Divers. 2011, 50, 189-225. [CrossRef]

41. Gomes, R.R.; Glienke, C.; Videira, S.I.R.; Lombard, L.; Groenewald, J.Z.; Crous, P.W. Diaporthe: A genus of endophytic, saprobic and plant pathogenic fungi. Persoonia 2013, 31,1-41. [CrossRef] 
42. Savi, D.C.; Aluizio, R.; Glienke, C. Brazilian plants: An unexplored source of endophytes as producers of active metabolites. Planta Med. 2019, 85, 619-636.

43. Huang, F.; Hou, X.; Dewdney, M.M.; Fu, Y.; Chen, G.; Hyde, K.D.; Li, H. Diaporthe species occurring on citrus in China. Fungal Divers. 2013, 61, 237-250. [CrossRef]

44. Guarnaccia, V.; Crous, P.W. Emerging citrus diseases in Europe caused by species of Diaporthe. IMA Fungus 2017, 8, 317-334. [CrossRef]

45. Huang, F.; Udayanga, D.; Wang, X.; Hou, X.; Mei, X.; Fu, Y.; Hyde, K.D.; Li, H. Endophytic Diaporthe associated with Citrus: A phylogenetic reassessment with seven new species from China. Fungal Biol. 2015, 119, 331-347. [CrossRef]

46. Peever, T.L.; Canihos, Y.; Olsen, L.; Ibáñez, A.; Liu, Y.C.; Timmer, L.W. Population genetic structure and host specificity of Alternaria spp. causing brown spot of Minneola tangelo and rough lemon in Florida. Phytopathology 1999, 89, 851-860. [CrossRef]

47. Akimitsu, K.; Peever, T.L.; Timmer, L.W. Molecular, ecological and evolutionary approaches to understanding Alternaria diseases of citrus. Mol. Plant Pathol. 2003, 4, 435-446. [CrossRef]

48. Sadeghi, F.; Samsampour, D.; Seyahooei, M.A.; Bagheri, A.; Soltani, J. Diversity and spatiotemporal distribution of fungal endophytes associated with Citrus reticulata cv. Siyahoo. Curr. Microbiol. 2019, 76, 279-289. [CrossRef]

49. Juybari, H.Z.; Tajick Ghanbary, M.A.; Rahimian, H.; Karimi, K.; Arzanlou, M. Seasonal, tissue and age influences on frequency and biodiversity of endophytic fungi of Citrus sinensis in Iran. For. Pathol. 2019, e12559. [CrossRef]

50. Sandoval-Denis, M.; Guarnaccia, V.; Polizzi, G.; Crous, P.W. Symptomatic Citrus trees reveal a new pathogenic lineage in Fusarium and two new Neocosmospora species. Persoonia 2018, 40, 1-25. [CrossRef]

51. Childs, J.F.L.; Kopp, L.E.; Johnson, R.E. A species of Physoderma present in Citrus and related species. Phytopathology 1965, 55, 681-687.

52. Ho, M.Y.; Chung, W.C.; Huang, H.C.; Chung, W.H.; Chung, W.H. Identification of endophytic fungi of medicinal herbs of Lauraceae and Rutaceae with antimicrobial property. Taiwania 2012, 57, 229-241.

53. Santos Gai, C.; Teixeira Lacava, P.; Maccheroni, W., Jr.; Glienke, C.; Araújo, W.L.; Miller, T.A.; Azevedo, J.L. Diversity of endophytic yeasts from sweet orange and their localization by scanning electron microscopy. $J$. Basic Microbiol. 2009, 49, 441-451.

54. Rodríguez, P.; Reyes, B.; Barton, M.; Coronel, C.; Menéndez, P.; Gonzalez, D.; Rodríguez, S. Stereoselective biotransformation of $\alpha$-alkyl- $\beta$-keto esters by endophytic bacteria and yeast. J. Mol. Catal. B Enzym. 2011, 71, 90-94. [CrossRef]

55. Bamisile, B.S.; Dash, C.K.; Akutse, K.S.; Qasim, M.; Ramos Aguila, L.C.; Wang, F.; Keppanan, R.; Wang, L. Endophytic Beauveria bassiana in foliar-treated Citrus limon plants acting as a growth suppressor to three successive generations of Diaphorina citri Kuwayama (Hemiptera: Liviidae). Insects 2019, 10, 176. [CrossRef]

56. Araújo, W.L.; Maccheroni, W., Jr.; Aguilar-Vildoso, C.I.; Barroso, P.A.; Saridakis, H.O.; Azevedo, J.L. Variability and interactions between endophytic bacteria and fungi isolated from leaf tissues of citrus rootstocks. Can. J. Microbiol. 2001, 47, 229-236. [CrossRef]

57. Glienke-Blanco, C.; Aguilar-Vildoso, C.I.; Vieira, M.L.C.; Barroso, P.A.V.; Azevedo, J.L. Genetic variability in the endophytic fungus Guignardia citricarpa isolated from citrus plants. Genet. Mol. Biol. 2002, 25, 251-255. [CrossRef]

58. Manoharan, G.; Sairam, T.; Thangamani, R.; Ramakrishnan, D.; Tiwari, M.K.; Lee, J.K.; Marimuthu, J. Identification and characterization of type III polyketide synthase genes from culturable endophytes of ethnomedicinal plants. Enzyme Microb. Technol. 2019, 131, 109396. [CrossRef]

59. Ling, L.; Li, Z.; Jiao, Z.; Zhang, X.; Ma, W.; Feng, J.; Zhang, J.; Lu, L. Identification of novel endophytic yeast strains from tangerine peel. Curr. Microbiol. 2019, 76, 1066-1072. [CrossRef]

60. Paz, Z.; Burdman, S.; Gerson, U.; Sztejnberg, A. Antagonistic effects of the endophytic fungus Meira geulakonigii on the citrus rust mite Phyllocoptruta oleivora. J. Appl. Microbiol. 2007, 103, 2570-2579. [CrossRef]

61. Pena, L.C.; Jung, L.F.; Savi, D.C.; Servienski, A.; Aluizio, R.; Goulin, E.H.; Galli-Terasawa, L.V.; Lameiro de Noronha Sales Maia, B.H.; Annies, V.; Cavichiolo Franco, C.R.; et al. A Muscodor strain isolated from Citrus sinensis and its production of volatile organic compounds inhibiting Phyllosticta citricarpa growth. J. Plant Dis. Prot. 2017, 124, 349-360. [CrossRef] 
62. Rodrigues, K.F.; Sieber, T.N.; Grünig, C.R.; Holdenrieder, O. Characterization of Guignardia mangiferae isolated from tropical plants based on morphology, ISSR-PCR amplifications and ITS1-5.8 S-ITS2 sequences. Mycol. Res. 2004, 108, 45-52. [CrossRef]

63. Miles, A.K.; Tan, Y.P.; Tan, M.K.; Donovan, N.J.; Ghalayini, A.; Drenth, A. Phyllosticta spp. on cultivated citrus in Australia. Australas. Plant Pathol. 2013, 42, 461-467. [CrossRef]

64. Schüepp, H. Untersuchungen über Guignardia citricarpa Kiely, den Erreger der Schwarzfleckenkrankheit auf Citrus. J. Phytopathol. 1960, 40, 258-271. [CrossRef]

65. Azevedo, J.L.; Maccheroni, W., Jr.; Pereira, J.O.; de Araújo, W.L. Endophytic microorganisms: A review on insect control and recent advances on tropical plants. Electron. J. Biotechnol. 2000, 3, 15-16. [CrossRef]

66. Hawksworth, D.L.; Crous, P.W.; Redhead, S.A.; Reynolds, D.R.; Samson, R.A.; Seifert, K.A.; Taylor, J.W.; Wingfield, M.J.; Abaci, O.; Aime, C.; et al. The Amsterdam declaration on fungal nomenclature. IMA Fungus 2011, 2, 105-112. [CrossRef]

67. Davis, E.C.; Franklin, J.B.; Shaw, A.J.; Vilgalys, R. Endophytic Xylaria (Xylariaceae) among liverworts and angiosperms: Phylogenetics, distribution, and symbiosis. Am. J. Bot. 2003, 90, 1661-1667. [CrossRef]

68. U’Ren, J.M.; Miadlikowska, J.; Zimmerman, N.B.; Lutzoni, F.; Stajich, J.E.; Arnold, A.E. Contributions of North American endophytes to the phylogeny, ecology, and taxonomy of Xylariaceae (Sordariomycetes, Ascomycota). Mol. Phylogenet. Evol. 2016, 98, 210-232. [CrossRef]

69. Nicoletti, R.; Fiorentino, A. Plant bioactive metabolites and drugs produced by endophytic fungi of Spermatophyta. Agriculture 2015, 5, 918-970. [CrossRef]

70. Camargo Dos Santos, P.J.; Savi, D.C.; Rodrigues Gomes, R.; Goulin, E.H.; Da Costa Senkiv, C.; Ossamu Tanaka, F.A.; Rodrigues Almeida, A.M.; Galli-Terasawa, L.; Kava, V.; Glienke, C. Diaporthe endophytica and D. terebinthifolii from medicinal plants for biological control of Phyllosticta citricarpa. Microbiol. Res. 2016, 186, 153-160. [CrossRef]

71. Hartley, S.E.; Gange, A.C. Impacts of plant symbiotic fungi on insect herbivores: Mutualism in a multitrophic context. Ann. Rev. Entomol. 2009, 54, 323-342. [CrossRef]

72. Eberl, F.; Uhe, C.; Unsicker, S.B. Friend or foe? The role of leaf-inhabiting fungal pathogens and endophytes in tree-insect interactions. Fungal Ecol. 2019, 38, 104-112. [CrossRef]

73. Martinuz, A.; Schouten, A.; Menjivar, R.D.; Sikora, R.A. Effectiveness of systemic resistance toward Aphis gossypii (Hom., Aphididae) as induced by combined applications of the endophytes Fusarium oxysporum Fo162 and Rhizobium etli G12. Biol. Control 2012, 62, 206-212. [CrossRef]

74. Bogner, C.W.; Kamdem, R.S.; Sichtermann, G.; Matthäus, C.; Hölscher, D.; Popp, J.; Proksch, P.; Grundler, F.M.; Schouten, A. Bioactive secondary metabolites with multiple activities from a fungal endophyte. Microb. Biotechnol. 2017, 10, 175-188. [CrossRef] [PubMed]

75. Brakhage, A.A.; Schroeckh, V. Fungal secondary metabolites-strategies to activate silent gene clusters. Fungal Genet. Biol. 2011, 48, 15-22. [CrossRef] [PubMed]

76. Deepika, V.B.; Murali, T.S.; Satyamoorthy, K. Modulation of genetic clusters for synthesis of bioactive molecules in fungal endophytes: A review. Microbiol. Res. 2016, 182, 125-140. [CrossRef] [PubMed]

77. Kumaran, R.S.; Muthumary, J.; Hur, B.K. Taxol from Phyllosticta citricarpa, a leaf spot fungus of the angiosperm Citrus medica. J. Biosci. Bioeng. 2008, 106, 103-106. [CrossRef] [PubMed]

78. Nicoletti, R.; Fiorentino, A. Antitumor metabolites of fungi. Curr. Bioact. Comp. 2014, 10, 207-244. [CrossRef]

79. Savi, D.C.; Shaaban, K.A.; Mitra, P.; Ponomareva, L.V.; Thorson, J.S.; Glienke, C.; Rohr, J. Secondary metabolites produced by the citrus phytopathogen Phyllosticta citricarpa. J. Antibiot. 2019, 72, 306-310. [CrossRef]

80. Buckel, I.; Andernach, L.; Schüffler, A.; Piepenbring, M.; Opatz, T.; Thines, E. Phytotoxic dioxolanones are potential virulence factors in the infection process of Guignardia bidwellii. Sci. Rep. 2017, 7, 8926. [CrossRef]

81. Yuan, W.H.; Liu, M.; Jiang, N.; Guo, Z.K.; Ma, J.; Zhang, J.; Song, Y.C.; Tan, R.X. Guignardones A-C: Three meroterpenes from Guignardia mangiferae. Eur. J. Org. Chem. 2010, 33, 6348-6353. [CrossRef]

82. Guimarães, D.O.; Lopes, N.P.; Pupo, M.T. Meroterpenes isolated from the endophytic fungus Guignardia mangiferae. Phytochem. Lett. 2012, 5, 519-523. [CrossRef]

83. Han, W.B.; Dou, H.; Yuan, W.H.; Gong, W.; Hou, Y.Y.; Ng, S.W.; Tan, R.X. Meroterpenes with toll-like receptor 3 regulating activity from the endophytic fungus Guignardia mangiferae. Planta Med. 2015, 81, 145-151. [CrossRef] 
84. Sun, Z.H.; Liang, F.L.; Wu, W.; Chen, Y.C.; Pan, Q.L.; Li, H.H.; Ye, W.; Liu, H.X.; Li, S.N.; Tan, G.H.; et al. Guignardones P-S, new meroterpenoids from the endophytic fungus Guignardia mangiferae A348 derived from the medicinal plant smilax glabra. Molecules 2015, 20, 22900-22907. [CrossRef]

85. Chen, K.; Zhang, X.; Sun, W.; Liu, J.; Yang, J.; Chen, C.; Liu, X.; Gao, L.; Wang, J.; Li, H.; et al. Manginoids A-G: Seven monoterpene-shikimate-conjugated meroterpenoids with a spiro ring system from Guignardia mangiferae. Org. Lett. 2017, 19, 5956-5959. [CrossRef]

86. Li, T.X.; Yang, M.H.; Wang, X.B.; Wang, Y.; Kong, L.Y. Synergistic antifungal meroterpenes and dioxolanone derivatives from the endophytic fungus Guignardia sp. J. Nat. Prod. 2015, 78, 2511-2520. [CrossRef]

87. Eze, P.M.; Ojimba, N.K.; Abonyi, D.O.; Chukwunwejim, C.R.; Abba, C.C.; Okoye, F.B.C.; Esimone, C.O. Antimicrobial activity of metabolites of an endophytic fungus isolated from the leaves of Citrus jambhiri (Rutaceae). Trop. J. Nat. Prod. Res. 2018, 2, 145-149. [CrossRef]

88. Doty, S.L. Growth-promoting endophytic fungi of forest trees. In Endophytes of Forest Trees; Pirttilä, A., Frank, A., Eds.; Springer: Berlin, Germany, 2011; pp. 151-156.

89. Waqas, M.; Khan, A.L.; Kamran, M.; Hamayun, M.; Kang, S.M.; Kim, Y.H.; Lee, I.J. Endophytic fungi produce gibberellins and indoleacetic acid and promotes host-plant growth during stress. Molecules 2012, 17, 10754-10773. [CrossRef]

90. Suwannarach, N.; Kumla, J.; Bussaban, B.; Nuangmek, W.; Matsui, K.; Lumyong, S. Biofumigation with the endophytic fungus Nodulisporium spp. CMU-UPE34 to control postharvest decay of citrus fruit. Crop Prot. 2013, 45, 63-70. [CrossRef]

91. Gomes, A.A.M.; Queiroz, M.V.; Pereira, O.L. Mycofumigation for the biological control of post-harvest diseases in fruits and vegetables: A review. Austin J. Biotechnol. Bioeng. 2015, 2, 1051.

92. Kaddes, A.; Fauconnier, M.L.; Sassi, K.; Nasraoui, B.; Jijakli, M.H. Endophytic fungal volatile compounds as solution for sustainable agriculture. Molecules 2019, 24, 1065. [CrossRef]

93. Huang, Z.; Yang, J.; Cai, X.; She, Z.; Lin, Y. A new furanocoumarin from the mangrove endophytic fungus Penicillium sp. (ZH16). Nat. Prod. Res. 2012, 26, 1291-1295. [CrossRef]

94. Zaher, A.M.; Moharram, A.M.; Davis, R.; Panizzi, P.; Makboul, M.A.; Calderón, A.I. Characterisation of the metabolites of an antibacterial endophyte Botryodiplodia theobromae Pat. of Dracaena draco L. by LC-MS/MS. Nat. Prod. Res. 2015, 29, 2275-2281. [CrossRef]

95. Balakumaran, M.D.; Ramachandran, R.; Kalaichelvan, P.T. Exploitation of endophytic fungus, Guignardia mangiferae for extracellular synthesis of silver nanoparticles and their in vitro biological activities. Microbiol. Res. 2015, 178, 9-17. [CrossRef]

96. Busby, P.E.; Ridout, M.; Newcombe, G. Fungal endophytes: Modifiers of plant disease. Plant Mol. Biol. 2016, 90, 645-655. [CrossRef]

97. Schlaeppi, K.; Bulgarelli, D. The plant microbiome at work. Mol. Plant Microbe Interact. 2015, 28, $212-217$. [CrossRef]

98. Ahlholm, J.U.; Helander, M.; Henriksson, J.; Metzler, M.; Saikkonen, K. Environmental conditions and host genotype direct genetic diversity of Venturia ditricha, a fungal endophyte of birch trees. Evolution 2002, 56, 1566-1573. [CrossRef]

99. Balint, M.; Tiffin, P.; Hallstrom, B.; O’Hara, R.B.; Olson, M.S.; Fankhauser, J.D.; Piepenbring, M.; Schmitt, I. Host genotype shapes the foliar fungal microbiome of balsam poplar (Populus balsamifera). PLoS ONE 2013, 8, e53987. [CrossRef]

(C) 2019 by the author. Licensee MDPI, Basel, Switzerland. This article is an open access article distributed under the terms and conditions of the Creative Commons Attribution (CC BY) license (http://creativecommons.org/licenses/by/4.0/). 